\title{
Specialized Fungal Parasites and Opportunistic Fungi in Gardens of Attine Ants
}

\author{
Fernando C. Pagnocca, ${ }^{1}$ Virginia E. Masiulionis, ${ }^{1}$ and Andre Rodrigues ${ }^{1,2}$ \\ ${ }^{1}$ Centre for the Study of Social Insects, São Paulo State University (UNESP), 13506-900 Rio Claro, SP, Brazil \\ ${ }^{2}$ Department of Biochemistry and Microbiology, São Paulo State University (UNESP), 13506-900 Rio Claro, SP, Brazil
}

Correspondence should be addressed to Andre Rodrigues, andrer@rc.unesp.br

Received 1 September 2011; Revised 2 November 2011; Accepted 5 November 2011

Academic Editor: Volker Witte

Copyright (C) 2012 Fernando C. Pagnocca et al. This is an open access article distributed under the Creative Commons Attribution License, which permits unrestricted use, distribution, and reproduction in any medium, provided the original work is properly cited.

Ants in the tribe Attini (Hymenoptera: Formicidae) comprise about 230 described species that share the same characteristic: all coevolved in an ancient mutualism with basidiomycetous fungi cultivated for food. In this paper we focused on fungi other than the mutualistic cultivar and their roles in the attine ant symbiosis. Specialized fungal parasites in the genus Escovopsis negatively impact the fungus gardens. Many fungal parasites may have small impacts on the ants' fungal colony when the colony is balanced, but then may opportunistically shift to having large impacts if the ants' colony becomes unbalanced.

\section{Introduction}

Restricted to the New World, the approximately 230 fungusgrowing ant species in the tribe Attini cultivate basidiomycetous fungi on freshly harvested plant substrate [1-3]. A wellknown subset of species in this tribe, the leaf-cutting ants, are considered the most important herbivores in the Neotropics $[4,5]$, due to the large amount of fresh leaves and flower parts that workers cut and use to nourish the mutualistic fungal cultivar.

The attine ant-fungal symbiosis is ancient and probably originated from ancestral ants occurring in the Amazon basin about 50 million years ago $[6,7]$. Since then, the tribe Attini evolved five patterns of fungiculture that are currently recognized [6]. Thus, the lower and higher attine ant genera practice different types of fungiculture, which are classified according to the type of fungus and the type of substrates used to maintain the fungal partner [6]. Therefore, the various fungiculture can be defined as (i) lower attine agriculture performed by phylogenetically basal ant genera such as Cyphomyrmex, Mycetagroicus, and Mycetophylax which cultivate fungi in the tribe Leucocoprini $[8,9]$, (ii) a specific type of agriculture performed by some species of the lower attine genus Apterostigma, which cultivates fungi within the family Pterulaceae (the "coral fungi" [10,11]), (iii) a group of ants that cultivate Leucocoprini fungi in the yeast form (ants in the Cyphomyrmex rimosus group), (iv) the higher attine agriculture that encompass the derived genera Trachymyrmex and Sericomyrmex which cultivate phylogenetically derived fungi within the Leucocoprini, mostly on fallen vegetation or organic matter, and finally (v) a specific group of ants within the higher agriculture, the leaf-cutting ants, cultivate a recent clade of derived Leucocoprini fungi [12].

Evidence shows that attine ants domesticated their fungal cultivars during the evolution of the symbiosis [8]. Thus, the evolutionary history of fungus-growing ants was marked by several horizontal transfers (switches) of cultivars. Particularly, within the lower attine fungiculture these cultivar switches occurred multiple times [8]. Mikheyev et al. [13] demonstrated that leaf-cutting ants cultivate the same species of cultivar, Leucoagaricus gongylophorus in an association known as "many to one." Interestingly, it was found that in colonies of leaf-cutting ant, just a single clone of the mutualistic fungus is cultivated by workers $[14,15]$.

Since the detailed study by Möller [16], it is known that attine fungiculture is continuously exposed to alien microorganisms. As fungus-growing ants rely on the mutualistic fungi as the main food source for the colony, fungiculture 
requires from workers several mechanisms to keep their cultivars protected from alien microorganisms that would harm the symbiosis [17].

The most important strategies applied by attine ants in order to preserve their nests from harmful microbes consist of mechanical and chemical barriers including (i) careful cleaning of the leaf fragments used as substrate for the fungal cultivar in order to put away spores and microorganisms $[18,19]$; (ii) massive inoculation of the mutualistic fungus mycelium onto the clean plant fragment increasing the colonization of this substrate by the cultivar [2]; (iii) the use of antimicrobial glandular secretions [20-24] and faecal droplets [25, 26]; (iv) weeding and grooming of infected parts of the garden when an undesired microorganism is detected [18]; (v) antagonistic activity of the mutualistic fungus against alien microorganisms [14, 19]; (vi) unspecific microbial interrelationship between microorganisms which benefit the whole nest [26]; (vii) control of humidity in disposal chambers [27]; (viii) association with antibioticproducing bacteria [28-36]. Despite such mechanisms to suppress the development of alien microbes, a plethora of bacteria, filamentous fungi and yeasts are still found in ant gardens [35, 37-41].

Fungi on the genus Escovopsis are considered specialized parasites of attine gardens while others are consistently isolated in association with attine gardens and need further studies to understand their role as symbionts. Here, we focus on Escovopsis sp. and the additional filamentous fungi and yeasts found in attine gardens and address the few studies that have explored the role of such microorganisms in the attine ant-fungal symbiosis.

\section{Escovopsis sp.: The Specialized Garden Parasite of Fungus-Growing Ants}

The existence of the anamorphic fungus of the genus Escovopsis (Figure 1) was observed by various researchers $[2,42]$ and was uniquely discussed for the first time by Möller [16]. Recently, Currie et al. [37] reported that Escovopsis sp. is associated with several genera of attine ants and is considered a parasite of the fungus cultivated by these insects [43]. Except for fungus-growing ants in the Cyphomyrmex rimosus group, this parasite has been found in most attine ant genera with frequency of occurrence ranging from $11 \%$ to $75 \%[37,38,44,45]$.

Escovopsis sp. can affect fungus gardens in various manners: in extreme cases, the parasite grows rapidly over the colony, resulting into its total collapse [45] (Figure 2). According to experiments conducted by Currie [45], Escovopsis can remain in the colony for an extended period of time, thereby, suppressing subsequent colony development. Such impacts on the ant colony are supposed to be due to the necrotrophic action of Escovopsis sp. towards the cultivar [43].

With respect to the occurrence of Escovopsis, so far, this parasite was not recorded from any other environmental source other than in association with attine ants, a pointer to a long history of coevolution with these ants and their mutualistic fungi [46]. This ancient evolutionary pattern resulted in broad phylogenetic associations between the various types of fungiculture and specific phylogenetic lineages of Escovopsis [46-49] as it is the case of the relationship of this mycoparasite and ants in the genus Apterostigma that are naturally threatened by a specific lineage of Escovopsis sp. [44]. This lineage comprises four Escovopsis morphotypes defined on the basis of conidial colours ranging between white, yellow, pink, or brown [44].

Meanwhile, within a particular fungiculture group, the same Escovopsis sp. strain can be associated with many genera of ants and vice versa, demonstrating that the interrelationship is apparently nonspecific or weak at a finer phylogenetic level $[50,51]$. Even in the same nest, different Escovopsis strains can be found as confirmed in the work of Taerum et al. [52], who verified that $67 \%$ of the colonies of Atta sp. and Acromyrmex sp. were infected by multiple strains of the parasite. Interestingly, such strains did not engage in interference competition for their hosts [52].

So far, only two species are formally recognized in this genus, namely, Escovopsis weberi [53] and Escovopsis aspergilloides [54]. These species were originally isolated from gardens of Atta sp. (in Brazil) and Trachymyrmex ruthae (in Trinidad and Tobago), respectively. Available data indicate that there exists a high variation in the morphology and genetic characteristics among strains of the two currently known Escovopsis species [44], suggesting that putative new species in this genus may be described in the near future $[44,55]$.

Several aspects of the biology of Escovopsis sp. still remain undiscovered. Nothing is known about their life cycle or whether there is a teleomorphic (sexual) state. Also, the mode of transmission between colonies is unknown. Regarding this aspect, Currie et al. [37] suggest that transmission may be through other arthropods that visit or inhabit the nests, such as mites. As a matter of fact, vertical transmission (from parental to offspring colonies) of this fungus has not been observed.

Considering the harmful effect and close relationship with the attine cultivar [49], it is not surprising to consider that this parasite could be used as a biocontrol agent. Accordingly, Folgarait et al. [56] studied the antagonistic effect of Escovopsis sp. towards three strains of the mutualistic fungus. The authors' findings indicate that, under in vitro conditions, Escovopsis sp. retarded the growth of the mutualistic fungus of Acromyrmex lundii and this effect is Escovopsis strain dependent. Similar results were previously reported by Silva et al. [57] in in vitro bioassays using one Escovopsis sp. strain and the mutualistic fungus of $A$. sexdens rubropilosa.

Despite these preliminary results about Escovopsis sp. as a potential agent of biological control, the ants' defensive mechanisms need to be considered. As a result of Escovopsis sp. infection ant colonies first mount a generalized response through a large mobilization of the individuals [58]. Second, workers physically remove and concentrate spores in the infrabuccal cavity $[18,59]$ (grooming); in addition, workers remove affected parts of the fungus gardens [18] (weeding). Regarding these two ant behaviours, there seems to exist caste specialization [60] and recruitment of workers to the site 


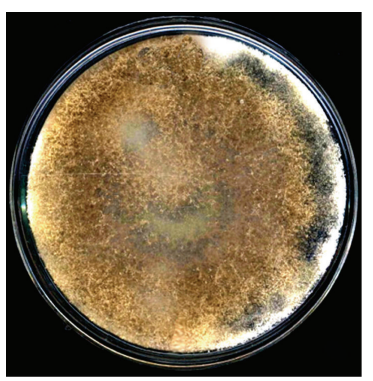

(a)

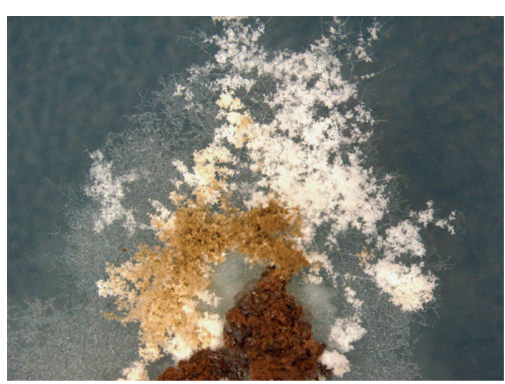

(b)

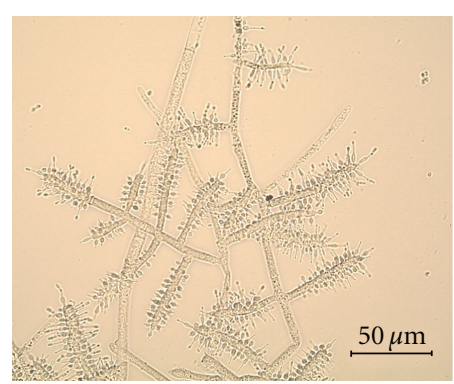

(c)

Figure 1: Escovopsis sp. parasites from fungus-growing ants. (a) General aspect of Escovopsis sp. isolated from the leaf-cutting ant Atta sexdens rubropilosa (Corumbataí, Brazil) cultured in potato dextrose agar (PDA) for 6 days at $25^{\circ} \mathrm{C}$. (b) Close view of Escovopsis sp. isolated from Acromyrmex lobicornis (Santa Fé, Argentina) in PDA after 5 days at $25^{\circ} \mathrm{C}$. (c) Escovopsis sp. conidiophores from (a). Note the cylindrical vesicles covered with ampulliform phialides.

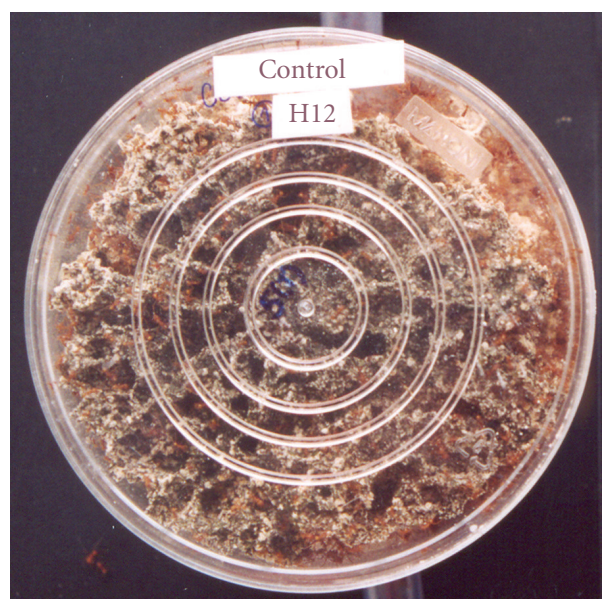

(a)

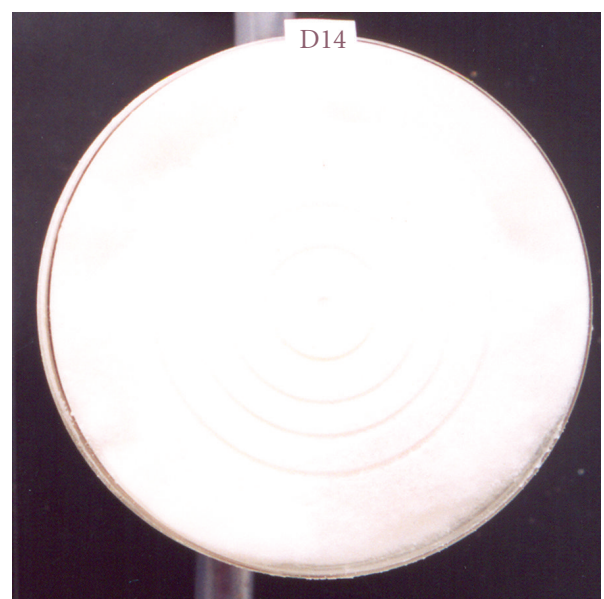

(b)

Figure 2: Laboratory colonies of Atta sexdens rubropilosa (Corumbataí, Brazil). Colonies were treated with baits without insecticide, control (a) and formulated baits containing the insecticide Hydramethylnon (b). Escovopsis sp. (white mycelia) emerged two days after treatment from fungus gardens of the infected colony (b), which depicts the aggressive effect of such parasite on attine ant colonies.

of infection [61]. An additional important factor that may impair the use of Escovopsis as agent of biological control is their low spore viability (about 3\% viability [24]) and it should be considered on the development of biological control methods.

Perhaps the most effective defensive mechanism against Escovopsis sp. is the association of attine ants with microbial symbionts capable of producing antifungal substances. For example, ants are associated with Pseudonocardia, a group of bacteria found in the ant's exoskeleton that antagonize Escovopsis sp. and which is vertically transmitted during the foundation of new nests $[28,62]$. Additionally, other microorganisms may antagonize Escovopsis sp. such as Amycolatopsis sp. [35], Burkholderia sp. [63], Streptomyces [32, 34, $35,64]$, and yeasts [65]. Thus, rather than a one-to-one symbiosis between the ants and their fungi, recent work suggests that rather the ants rely on a consortium of microbes and their compounds to defend themselves against Escovopsis sp. parasites [26].

\section{Occurrence of Additional Fungi on Gardens of Attine Ants and Their Possible Role as Symbionts}

Evolutionary theory predicts that organisms with restricted genetic diversity are susceptible to exploitation by several parasites [66]. This can be the case of attine ants which cultivate a single strain of the mutualistic fungus [14, 15]. Since the fungus garden is an ideal environment for the growth of the fungal cultivar, it is expected that additional alien fungi would exploit this substrate.

As indicated earlier, Möller [16] was the first to record the existence of filamentous fungi in attine gardens. In addition to the fungus that was latter named Escovopsis sp. and to which the author referred as the "strong state" of the mutualist cultivar, Möller [16] provided detailed information on the occurrence of Aspergillus sp., Mucor sp., Penicillium, and Rhizopus sp. on the fungus gardens of Acromyrmex disciger (collected in Blumenau, Brazil). This author reported 
that such filamentous fungi covered the fungus gardens when left unattended by workers. Later, Spegazzini [67] found ascocarps of Xylaria micrura in abandoned nests of Acromyrmex lundii in Argentina and also provided detailed drawings of this structure. When working with laboratory nests of Trachymyrmex septentrionalis, Weber [68] observed that gardens were also overgrown by several filamentous fungi such as Aspergillus sp., Mucor sp., and Penicillium sp. Kreisel [42] also observed Cunninghamella sp., Fusarium sp., Rhizopus sp., and Trichoderma sp. when studying fungus gardens of Atta insularis (in Cuba) unattended by workers. Similarly, Bass and Cherrett [69] studying the roles that workers play on the fungus garden maintenance observed that Aspergillus sp., Cladosporium sp., Fusarium sp., Mucor sp. and Penicillium sp. quickly overgrow gardens when left unattended by workers for several days. Luciano et al. [70] found Aspergillus sp., Nigrospora sp., and Penicillium sp. growing on the fungus garden of laboratory colonies of Acromyrmex heyeri in south Brazil.

Fisher et al. [39] demonstrated that Atta cephalotes colonies reared in the laboratory presented a shift in the fungal species composition when offered different plant substrates, thus providing the first experimental evidence that the fungal community on attine gardens may be influenced by the type of plant substrate used in the experiments. In addition, Currie et al. [37] demonstrated that gardens from diverse attine ant genera spanning all the phylogenetic diversity of the tribe Attini harbor alien fungi. These authors studied mostly attine ants from Central America and particular attention was drawn to the garden parasite Escovopsis sp. but several other fungi also occurred which were not identified [37]. Following this study, Ortiz et al. [71] reported the occurrence of Fusarium sp., Rhizopus sp., and Trichoderma lignorum when studying fungus garden fragments left unattended by workers of $A$. cephalotes (in Colombia). Barbosa et al. [72] and Barbosa [73] also reported a comprehensive list of species of filamentous fungi present in fungus gardens of Atta laevigata field nests in northeastern Brazil and concluded that the genus Trichoderma was prevalent in such gardens.

In addition to reports about filamentous fungi several authors also recorded a variety of yeasts on nests of attine ants. For example, Craven et al. [74] provided the first evidence that attine gardens contain yeasts using scanning electron microscopy. Pagnocca et al. [75] and Carreiro et al. [40] were the first to systematically study the yeast populations on laboratory colonies of $A$. sexdens rubropilosa. Such authors found variations in the abundance of yeasts populations in gardens and pointed out that Candida, Cryptococcus, Pichia, Rhodotorula, Sporobolomyces, Tremella, and Trichosporon were the prevalent genera. Carreiro et al. [76] showed that yeasts found on attine gardens produce the so-called killer toxins (or mycocins), which were proposed to be involved on the regulation of yeast populations on attine gardens. In this sense, Rodrigues et al. [65] proposed that yeasts may have a protective role in attine gardens against alien filamentous fungi. Up to date, the yeast survey on attine gardens rendered the description of three new species: Cryptococcus haglerorum [77], Blastobotrys attinorum (= Sympodiomyces attinorum [78]), and Trichosporon chiarellii [79]; however, there is evidence that additional new yeast species associated with these insects await discovery. Recently, black yeasts in the genus Phialophora were reported to live on the exoskeleton of attine ants $[80,81]$ and the authors pointed out that they could antagonize the protective role of their symbiotic Pseudonocardia. Polysaccharidases secreted by yeasts and bacteria $[82,83]$ may also be important for the nest homeostasis and it is an open field for further investigation.

Despite the proposed roles that yeasts may play on attine gardens, few studies focused on the potential roles that filamentous fungi may perform on the attine ant-fungal interaction. Several filamentous fungi found in attine gardens are commonly found in soil or plant substrates, suggesting that these microorganisms are probably transported on the workers' integument or introduced into gardens via the plant material collected by the foraging workers [38, 41, 84]. Thus, it has been suggested that filamentous fungi are present in the fungus gardens as transient spores and may not play significant roles in the symbiosis [85]. In agreement with this hypothesis, Currie and Stuart [18] observed that when Atta sp. gardens are experimentally infected with Trichoderma sp. spores (a generalist fungus in comparison to Escovopsis sp.), the ants groom out spores efficiently that it is apparently removed from gardens. In contrast, gardens infected with Escovopsis sp. spores sustained long-term infections. Thus, this result suggests that general fungi like Trichoderma sp. may not play any role in the symbiosis [18].

On the other hand, recent studies address that filamentous fungi may play important roles in gardens of fungusgrowing ants. Considering the studies reviewed here it is clear that a common trend arises: filamentous fungi (i) are found in association with diverse genera of attine ants, (ii) are found in attine nests from different localities, and, most important, (iii) quickly develop when the fungus gardens are unattended by workers (Figure 3 ).

In this sense, Rodrigues et al. [86] determined that the majority of microfungi found in gardens of $A$. sexdens rubropilosa, a leaf-cutting ant species spread all over Brazil, belong to genera commonly found in soil and plant substrate. Particularly, the fungus Syncephalastrum racemosum was found in $54 \%$ of gardens from laboratory nests treated with baits supplemented with the insecticide sulfluramid (commonly used in Brazil to control leaf-cutting ants). A variety of other fungi, including Fusarium solani, were found in such gardens but with fewer than $20 \%$ of prevalence. None of the laboratory nests used as control (either treated with Eucalyptus sp. leaves or baits without insecticide) had the fungus gardens overgrown by filamentous fungi. On the other hand, Fusarium oxysporum and Trichoderma harzianum were found in $23 \%$ and $38 \%$ of gardens from field nests treated with baits supplemented with sulfluramid, respectively. It is interesting to note that S. racemosum was not observed in gardens from nests treated with insecticides under field conditions [86]. In addition, Escovopsis sp. was isolated in $21 \%$ and $15 \%$ in gardens of laboratory and field nests treated with sulfluramid, respectively [86]. In another experiment, several microfungal species were observed to quickly overgrow the fungus garden of $A$. sexdens rubropilosa 


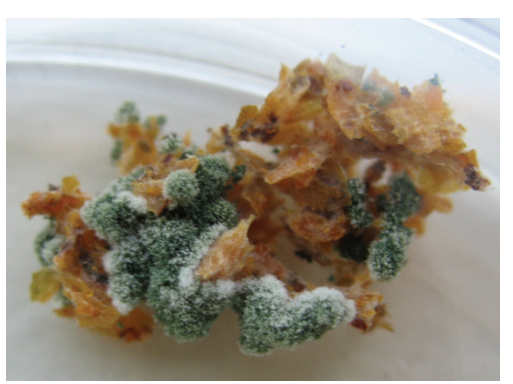

(a)

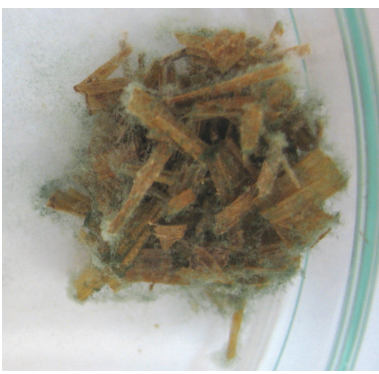

(b)

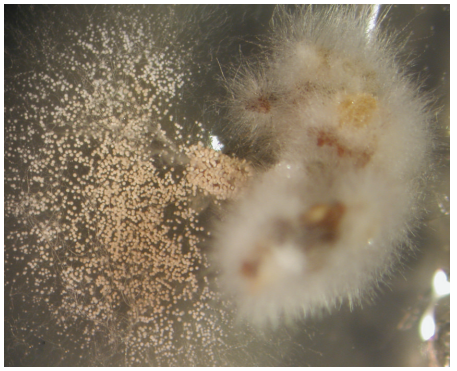

(c)

FIGURE 3: Fungus garden fragments of leaf-cutting ants overgrown by filamentous fungi. (a) Atta texana garden fragment (TX, USA) with green tufts of Trichoderma sp. (b) Atta bisphaerica garden fragment (Botucatu, Brazil) with green conidiation of Trichoderma sp. Workers from (a) and (b) were manually removed and garden fragments were kept in wet chambers for 5 days at $25^{\circ}$ C. (c) Isolation plate showing fungus garden fragment on potato dextrose agar medium supplemented with $150 \mu \mathrm{g} \cdot \mathrm{mL}^{-1}$ of chloramphenicol. On the right note the white mycelia of the mutualistic fungus of attine ants and on the left the microfungus Aspergillus sp. Both fungi emerged from the garden fragment.

( $n=12)$ when workers were experimentally removed [87]. The observed species included Acremonium kiliense (42\%), E. weberi (42\%), Trichoderma sp. (50\%), and a fungus previously identified as Moniliella suaveolens (50\%), which now is known to be a genus not yet described (Harry Evans, personal communication). Similarly, Carlos et al. [88] found several fungal species including Penicillium spp. and S. racemosum on $A$. sexdens rubropilosa gardens when treated with a variety of formulated insecticides.

In another systematic study, filamentous fungi were also reported from field nests of several species of Acromyrmex from south Brazil [38]. The authors observed a high diversity of fungi and noted that F. oxysporum, Escovopsis sp., and Cunninghamella binariae were present in 40.5\%, 27\%, and $19 \%$, respectively, out of 37 nests. In contrast with previous studies, S. racemosum was found in $5.4 \%$ of the nests. Recently, Rodrigues et al. [41] showed that Cyphomyrmex wheeleri ( $n=16$ nests), Trachymyrmex septentrionalis $(n=$ 16), and Atta texana $(n=4)$ sampled in Texas (USA) harbor a diverse community of microfungi which varies across seasons and are structured, in part, by location where nests were collected, reflecting a spatial component on the structuring of fungal communities. Interestingly, both Escovopsis sp. and S. racemosum were not found in the studied nests.

Moreover, many filamentous fungi are carried by the female alates (gynes) of leaf-cutting ants during the foundation of a new nest [89-91]. These microorganisms were more prevalent on the integument than in pellets found in the infrabuccal pocket $[37,91]$. Although such fungi may be accidentally transported by gynes, they compose the initial microbiota associated with the ant nests and might be involved in the success on the establishment of a new nest. In fact, Autuori $[92,93]$ reported that several incipient nests do not thrive the period following the nuptial flight. In addition to flooding and birds, this author argued that fungi were also responsible for the mortality of incipient nests [93].

An additional observation sheds light on the possible role of filamentous fungi as opportunistic antagonists. When laboratory subcolonies of $A$. sexdens rubropilosa were artificially infected with spores suspensions of Fusarium solani, Trichoderma cf. harzianum, S. racemosum, and E. weberi, Rodrigues et al. [94] observed that only nests treated with $E$. weberi provided a persistent infection (detected up to 300 hours after infection). However, about twelve hours after treatment with $S$. racemosum spores, workers removed fragments of fungus gardens and dumped away from gardens. This observation parallels the weeding behavior originally described as a specific adaptation for removing germinated spores of Escovopsis sp. [18]. Dumped fragments were collected and after plating quickly revealed the presence of S. racemosum [94].

In addition to Escovopsis sp. other filamentous fungi were thought to be used as biological control agents [95]. Thus, attempts to use fungal spores on bait formulations demonstrated the effectiveness of this approach. Formulated baits with a combination of spores of Metarhizium anisopliae (an insect pathogenic fungi) and Trichoderma viride (opportunistic antagonist of the ant cultivar) controlled $100 \%$ of laboratory colonies of Atta cephalotes compared to the control (nests treated with baits without spores) [95]. Field experiments showed that baits with $M$. anisopliae and $T$. viride spores achieved $100 \%$ of nest mortality when compared to the insecticide Pirimiphos-methyl, which caused $60 \%$ of nest mortality. However, the time necessary to achieve $100 \%$ of nest mortality using the formulated baits was more than 60 days [95], which is considered ineffective for controlling leaf-cutting ants in large areas. Despite the failure of such attempts these initiatives are desirable and perhaps will guide the development of alternative techniques to control these pest ants.

\section{Conclusions and Future Directions}

The evidence gathered so far suggests that filamentous fungi act as opportunistic antagonists on the attine antfungal interaction. In comparison to the specialized fungus Escovopsis sp., filamentous fungi are considered nonspecific antagonists of the ant cultivar. The antagonistic effect of these fungi is evident in disturbed gardens (either caused by insecticides or other unknown factor), when gardens are unattended by workers and on incipient nests. Future 
experimental studies should systematically address whether filamentous fungi also influence healthy colonies. The results of such studies will ultimately help in the development of new strategies for controlling leaf-cutting ants.

Finally, despite the arguments in favour of the antagonistic nature of filamentous fungi, we do not rule out that some may have other unknown functions in the attine ant symbiosis. For instance, Freinkman et al. [96] demonstrated that fungi may be a potential source of new compounds as it is the case of bionectriol A, isolated from Bionectria sp. derived from the fungus gardens of Apterostigma dentigerum. Perhaps, future reports will unravel the existence of filamentous fungi that are beneficial to the ant colony. This aspect is totally unexplored and should also be considered when studying such microorganisms.

\section{Acknowledgments}

The authors are grateful to FAPESP (Fundação de Amparo à Pesquisa do Estado de São Paulo) and CNPq (Conselho Nacional de Desenvolvimento Científico e Tecnológico) for finnancial support. V. E. Masiulionis is recipient of a scholarship from CAPES (PEC-PG). They also thank I. DayoOwoyemi for English review. They acknowledge the three anonymous reviewers for helpful comments on this paper.

\section{References}

[1] R. J. Powell and D. J. Stradling, "Factors influencing the growth of Atta bromatificus, a symbiont of attine ants," Transactions of the British Mycological Society, vol. 87, no. 2, pp. 205-213, 1986.

[2] N. A. Weber, Gardening Ants: The Attines, vol. 92, American Philosophical Society, Philadelphia, Pa, USA, 1972.

[3] M. Bass and J. M. Cherrett, "Fungal hyphae as a source of nutrients for the leaf-cutting ant Atta sexdens," Physiological Entomology, vol. 20, no. 1, pp. 1-6, 1995.

[4] H. R. Fowler, J. V. E. Bernardi, J. C. Delabie, L. C. Forti, and V. Pereira da Silva, "Major ant problems of South America," in Applied Myrmecology-A World Perspective, R. Vander Meer, K. Jaffe, and A. Cedeno, Eds., pp. 3-14, Westview Press, Oxford, UK, 1990.

[5] B. Hölldobler and E. O. Wilson, The Leafcutter Ants: Civilization by Instinct, Norton \& Company, New York, NY, USA, 2010.

[6] T. R. Schultz and S. G. Brady, "Major evolutionary transitions in ant agriculture," Proceedings of the National Academy of Sciences of the United States of America, vol. 105, no. 14, pp. 54355440, 2008.

[7] S. E. Solomon, M. Bacci Jr., J. Martins, G. G. Vinha, and U. G. Mueller, "Paleodistributions and comparative molecular phylogeography of leafcutter ants (Atta spp.) provide new insight into the origins of Amazonian diversity," PLoS One, vol. 3, no. 7, Article ID e2738, 2008.

[8] U. G. Mueller, S. A. Rehner, and T. R. Schultz, "The evolution of agriculture in ants," Science, vol. 281, no. 5385, pp. 20342038, 1998.

[9] S. E. Solomon, C. T. Lopes, U. G. Mueller et al., "Nesting biology and fungiculture of the fungus-growing ant, Mycetagroicus cerradensis: New light on the origin of higher attine agriculture," Journal of Insect Science, vol. 11, article 12, 2011.
[10] A. B. Munkacsi, J. J. Pan, P. Villesen, U. G. Mueller, M. Blackwell, and D. J. McLaughlin, "Convergent coevolution in the domestication of coral mushrooms by fungus-growing ants," Proceedings of the Royal Society B, vol. 271, no. 1550, pp. 17771782, 2004.

[11] P. Villesen, U. G. Mueller, T. R. Schultz, R. M. M. Adams, and A. C. Bouck, "Evolution of ant-cultivar specialization and cultivar switching in Apterostigma fungus-growing ants," Evolution, vol. 58, no. 10, pp. 2252-2265, 2004.

[12] A. S. Mikheyev, U. G. Mueller, and P. Abbot, "Comparative dating of attine ant and lepiotaceous cultivar phylogenies reveals coevolutionary synchrony and discord," American Naturalist, vol. 175, no. 6, pp. E126-E133, 2010.

[13] A. S. Mikheyev, U. G. Mueller, and P. Abbot, "Cryptic sex and many-to-one coevolution in the fungus-growing ant symbiosis," Proceedings of the National Academy of Sciences of the United States of America, vol. 103, no. 28, pp. 10702-10706, 2006.

[14] M. Poulsen and J. J. Boomsma, "Mutualistic fungi control crop diversity in fungus-growing ants," Science, vol. 307, no. 5710, pp. 741-744, 2005.

[15] U. G. Mueller, J. J. Scott, H. D. Ishak, M. Cooper, and A. Rodrigues, "Monoculture of leafcutter ant gardens," PLoS One, vol. 5, no. 9, Article ID e12668, 2010.

[16] A. Möller, "Die Pilzgärten einiger südamerikanischer Ameisen," Botanische Mitteilungen aus den Tropen, vol. 6, pp. 1-27, 1893.

[17] M. Poulsen, A. N. M. Bot, C. R. Currie, and J. J. Boomsma, "Mutualistic bacteria and a possible trade-off between alternative defence mechanisms in Acromyrmex leaf-cutting ants," Insectes Sociaux, vol. 49, no. 1, pp. 15-19, 2002.

[18] C. R. Currie and A. E. Stuart, "Weeding and grooming of pathogens in agriculture by ants," Proceedings of the Royal Society B, vol. 268, no. 1471, pp. 1033-1039, 2001.

[19] S. A. Van Bael, H. Fernández-Marín, M. C. Valencia, E. I. Rojas, W. T. Wcislo, and E. A. Herre, "Two fungal symbioses collide: endophytic fungi are not welcome in leaf-cutting ant gardens," Proceedings of the Royal Society B, vol. 276, no. 1666, pp. 2419-2426, 2009.

[20] A. J. Beattie, C. Turnbull, T. Hough, and R. B. Knox, "Antibiotic production: a possible function for the metapleural glands of ants (Hymenoptera: Formicidae)," Annals of the Entomological Society of America, vol. 79, no. 3, pp. 448-450, 1986.

[21] D. Ortius-Lechner, R. Maile, E. David Morgan, and J. J. Boomsma, "Metapleural gland secretion of the leaf-cutter ant Acromyrmex octospinosus: new compounds and their functional significance," Journal of Chemical Ecology, vol. 26, no. 7, pp. 1667-1683, 2000.

[22] A. L. Marsaro Júnior Jr., T. M. C. Della Lucia, L. C. A. Barbosa, L. A. Maffia, and M. A. B. Morandi, "Inhibition of the germination of Botrytis cinerea Pers. Fr. conidia by extracts of the mandibular gland of Atta sexdens rubropilosa forel (Hymenoptera: Formicidae)," Neotropical Entomology, vol. 30, no. 3, pp. 403-406, 2001.

[23] H. Fernández-Marín, J. K. Zimmerman, S. A. Rehner, and W. T. Wcislo, "Active use of the metapleural glands by ants in controlling fungal infection," Proceeding of the Royal Society of London, Series B, vol. 273, no. 1594, pp. 1689-1695, 2006.

[24] A. Rodrigues, C. D. Carletti, O. C. Bueno, and F. C. Pagnocca, "Leaf-cutting ant faecal fluid and mandibular gland secretion: effects on microfungi spore germination," Brazilian Journal of Microbiology, vol. 39, no. 1, pp. 64-67, 2008.

[25] N. D. Boyd and M. M. Martin, "Faecal proteinases of the fungus-growing ant, Atta texana: their fungal origin and 
ecological significance," Journal of Insect Physiology, vol. 21, no. 11, pp. 1815-1820, 1975.

[26] I. Schoenian, M. Spiteller, M. Ghaste, R. Wirth, H. Herz, and D. Spiteller, "Chemical basis of the synergism and antagonism in microbial communities in the nests of leaf-cutting ants," Proceedings of the National Academy of Sciences of the United States of America, vol. 108, no. 5, pp. 1955-1960, 2011.

[27] P. L. Ribeiro and C. A. Navas, "The leaf-cutting ant Atta sexdens rubropilosa, FOREL, 1908 prefers drier chambers for garbage disposal," Journal of Insect Behavior, vol. 20, no. 1, pp. 19-24, 2007.

[28] C. R. Currie, J. A. Scottt, R. C. Summerbell, and D. Malloch, "Fungus-growing ants use antibiotic-producing bacteria to control garden parasites," Nature, vol. 398, no. 6729, pp. 701704, 1999.

[29] C. R. Currie, A. N. M. Bot, and J. J. Boomsma, "Experimental evidence of a tripartite mutualism: bacteria protect ant fungus gardens from specialized parasites," Oikos, vol. 101, no. 1, pp. 91-102, 2003.

[30] M. Poulsen, M. J. Cafaro, D. P. Erhardt et al., "Variation in Pseudonocardia antibiotic defence helps govern parasiteinduced morbidity in Acromyrmex leaf-cutting ants," Environmental Microbiology Reports, vol. 2, no. 4, pp. 534-540, 2010.

[31] M. J. Cafaro, M. Poulsen, A. E.F. Little et al., "Specificity in the symbiotic association between fungus-growing ants and protective Pseudonocardia bacteria," Proceedings of the Royal Society B, vol. 278, no. 1713, pp. 1814-1822, 2011.

[32] C. Kost, T. Lakatos, I. Böttcher, W. R. Arendholz, M. Redenbach, and R. Wirth, "Non-specific association between filamentous bacteria and fungus-growing ants," Naturwissenschaften, vol. 94, no. 10, pp. 821-828, 2007.

[33] U. G. Mueller, D. Dash, C. Rabeling, and A. Rodrigues, "Coevolution between attine ants and actinomycete bacteria: a reevaluation," Evolution, vol. 62, no. 11, pp. 2894-2912, 2008.

[34] S. Haeder, R. Wirth, H. Herz, and D. Spiteller, "Candicidinproducing Streptomyces support leaf-cutting ants to protect their fungus garden against the pathogenic fungus Escovopsis," Proceedings of the National Academy of Sciences of the United States of America, vol. 106, no. 12, pp. 4742-4746, 2009.

[35] R. Sen, H. D. Ishak, D. Estrada, S. E. Dowd, E. Hong, and U. G. Mueller, "Generalized antifungal activity and 454-screening of Pseudonocardia and Amycolatopsis bacteria in nests of fungusgrowing ants," Proceedings of the National Academy of Sciences of the United States of America, vol. 106, no. 42, pp. 1780517810, 2009.

[36] J. Barke, R. F. Seipke, D. W. Yu, and M. I. Hutchings, "A mutualistic microbiome: How do fungus-growing ants select their antibiotic-producing bacteria?" Communicative \& Integrative Biology, vol. 4, no. 1, pp. 1-3, 2010.

[37] C. R. Currie, U. G. Mueller, and D. Malloch, "The agricultural pathology of ant fungus gardens," Proceedings of the National Academy of Sciences of the United States of America, vol. 96, no. 14, pp. 7998-8002, 1999.

[38] A. Rodrigues, M. Bacci Jr., U. G. Mueller, A. Ortiz, and F. C. Pagnocca, "Microfungal "weeds" in the leafcutter ant symbiosis," Microbial Ecology, vol. 56, no. 4, pp. 604-614, 2008.

[39] P. J. Fisher, D. J. Stradling, B. C. Sutton, and L. E. Petrini, "Microfungi in the fungus gardens of the leaf-cutting ant Atta cephalotes: a preliminary study," Mycological Research, vol. 100, no. 5, pp. 541-546, 1996.

[40] S. C. Carreiro, F. C. Pagnocca, O. C. Bueno, M. Bacci, M. J. A. Hebling, and O. A. Da Silva, "Yeasts associated with nests of the leaf-cutting ant Atta sexdens rubropilosa Forel, 1908," Antonie van Leeuwenhoek, vol. 71, no. 3, pp. 243-248, 1997.
[41] A. Rodrigues, U. G. Mueller, H. D. Ishak, M. Bacci Jr, and F. C. Pagnocca, "Ecology of microfungal communities in gardens of fungus-growing ants (Hymenoptera: Formicidae): a year-long survey of three species of attine ants in Central Texas," FEMS Microbiology Ecology, vol. 78, no. 2, pp. 244-255, 2011.

[42] H. Kreisel, "Fungi from fungus gardens of Atta insularis in Cuba," Zeitschrift fur Allgemeine Mikrobiologie, vol. 12, no. 8, pp. 643-654, 1972.

[43] H. T. Reynolds and C. R. Currie, "Pathogenicity of Escovopsis weberi: the parasite of the attine ant-microbe symbiosis directly consumes the ant-cultivated fungus," Mycologia, vol. 96, no. 5, pp. 955-959, 2004.

[44] N. M. Gerardo, U. G. Mueller, and C. R. Currie, "Complex host-pathogen coevolution in the Apterostigma fungus-growing ant-microbe symbiosis," BMC Evolutionary Biology, vol. 6, article no. 88, 2006.

[45] C. R. Currie, "Prevalence and impact of a virulent parasite on a tripartite mutualism,” Oecologia, vol. 128, no. 1, pp. 99-106, 2001.

[46] C. R. Currie, B. Wong, A. E. Stuart et al., "Ancient tripartite coevolution in the attine ant-microbe symbiosis," Science, vol. 299, no. 5605, pp. 386-388, 2003.

[47] N. J. Mehdiabadi and T. R. Schultz, "Natural history and phylogeny of the fungus-farming ants (Hymenoptera: Formicidae: Myrmicinae: Attini)," Myrmecological News, vol. 13, pp. 37-55, 2009.

[48] N. M. Gerardo, U. G. Mueller, S. L. Price, and C. R. Currie, "Exploiting a mutualism: parasite specialization on cultivars within the fungus-growing ant symbiosis," Proceedings of the Royal Society B, vol. 271, no. 1550, pp. 1791-1798, 2004.

[49] N. M. Gerardo, S. R. Jacobs, C. R. Currie, and U. G. Mueller, "Ancient host-pathogen associations maintained by specificity of chemotaxis and antibiosis," PLoS Biology, vol. 4, no. 8, pp. 1358-1363, 2006.

[50] S. J. Taerum, M. J. Cafaro, A. E. F. Little, T. R. Schultz, and C. R. Currie, "Low host-pathogen specificity in the leaf-cutting ant-microbe symbiosis," Proceedings of the Royal Society B, vol. 274, no. 1621, pp. 1971-1978, 2007.

[51] N. M. Gerardo and E. J. Caldera, "Labile associations between fungus-growing ant cultivars and their garden pathogens," ISME Journal, vol. 1, no. 5, pp. 373-384, 2007.

[52] S. J. Taerum, M. J. Cafaro, and C. R. Currie, "Presence of multiparasite infections within individual colonies of leaf-cutter ants," Environmental Entomology, vol. 39, no. 1, pp. 105$113,2010$.

[53] J. J. Muchovej and T. M. C. Della Lucia, "Escovopsis, a new genus from leaf-cutting ant nests to replace Phialocladus nomem invalidum," Mycotaxon, vol. 37, no. 1, pp. 191-195, 1990.

[54] K. A. Seifert, R. A. Samson, and I. H. Chapela, "Escovopsis aspergilloides, a rediscovered hyphomycete from leaf-cutting ant nests," Mycologia, vol. 87, no. 3, pp. 407-413, 1995.

[55] C. R. Currie, "A community of ants, fungi, and bacteria: a multilateral approach to studying symbiosis," Annual Review of Microbiology, vol. 55, pp. 357-380, 2001.

[56] P. Folgarait, N. Gorosito, M. Poulsen, and C. R. Currie, "Preliminary in vitro insights into the use of natural fungal pathogens of leaf-cutting ants as biocontrol agents," Current Microbiology, vol. 63, no. 3, pp. 250-258, 2011.

[57] A. Silva, A. Rodrigues, M. Bacci, F. C. Pagnocca, and O. C. Bueno, "Susceptibility of the ant-cultivated fungus Leucoagaricus gongylophorus (Agaricales: Basidiomycota) towards microfungi," Mycopathologia, vol. 162, no. 2, pp. 115-119, 2006. 
[58] A. G. Hart, A. N. M. Bot, and M. J. F. Brown, "A colonylevel response to disease control in a leaf-cutting ant," Naturwissenschaften, vol. 89, no. 6, pp. 275-277, 2002.

[59] A. E. F. Little, T. Murakami, U. G. Mueller, and C. R. Currie, "Defending against parasites: fungus-growing ants combine specialized behaviours and microbial symbionts to protect their fungus gardens," Biology Letters, vol. 2, no. 1, pp. 12-16, 2006.

[60] D. Abramowsky, C. R. Currie, and M. Poulsen, "Caste specialization in behavioural defences against fungus garden parasites in Acromyrmex octospinosus leaf-cutting ants," Insectes Sociaux, vol. 58, pp. 65-75, 2011.

[61] A. T. Gerstner, M. Poulsen, and C. R. Currie, "Recruitment of minor workers for defense against a specialized parasite of Atta leaf-cutting ant fungus gardens," Ethology Ecology and Evolution, vol. 23, no. 1, pp. 61-75, 2011.

[62] D. C. Oh, M. Poulsen, C. R. Currie, and J. Clardy, "Dentigerumycin: a bacterial mediator of an ant-fungus sym- biosis," Nature Chemical Biology, vol. 5, no. 6, pp. 391-393, 2009.

[63] A. V. Santos, R. J. Dillon, V. M. Dillon, S. E. Reynolds, and R. I. Samuels, "Ocurrence of the antibiotic producing bacterium Burkholderia sp. in colonies of the leaf-cutting ant Atta sexdens rubropilosa," FEMS Microbiology Letters, vol. 239, no. 2, pp. 319-323, 2004.

[64] T. D. Mendes, Atividade antimicrobiana de actinobactérias isoladas de formigas Attini (Hymenoptera: Formicidae), Master dissertation, UNESP, São Paulo, Brazil, 2010.

[65] A. Rodrigues, R. N. Cable, U. G. Mueller, M. Bacci, and F. C. Pagnocca, "Antagonistic interactions between garden yeasts and microfungal garden pathogens of leaf-cutting ants," Antonie van Leeuwenhoek, vol. 96, no. 3, pp. 331-342, 2009.

[66] W. D. Hamilton, R. Axelrod, and R. Tanese, "Sexual reproduction as an adaptation to resist parasites (A review)," Proceedings of the National Academy of Sciences of the United States of America, vol. 87, no. 9, pp. 3566-3573, 1990.

[67] C. Spegazzini, "Descripción de hongos mirmecófilos," Revista del Museo de La Plata, vol. 26, no. 3, pp. 166-173, 1922.

[68] N. A. Weber, "Pure cultures of fungi produced by ants," Science, vol. 121, no. 3134, p. 109, 1955.

[69] M. Bass and J. M. Cherrett, "The role of leaf-cutting ant workers (Hymenoptera: Formicidae) in fungus garden maintenance," Ecological Entomology, vol. 19, no. 3, pp. 215-220, 1994.

[70] H. M. Luciano, E. Diehl-Fleig, and M. E. Silva, "Organismos associados a uma colônia de Acromyrmex heyeri (Hymenoptera: Formicidae) mantida em laboratório," Acta Biologica Leopoldensia, vol. 17, no. 2, pp. 47-56, 1995.

[71] A. Ortiz, A. Madrigal, and S. Orduz, "Evaluación del comportamiento de las hormigas Atta cephalotes (Hymenoptera: Formicidae) frente a la contaminación del jardín del hongo con Trichoderma lignorum," Revista Colombiana de Entomología, vol. 25, no. 3-4, pp. 169-177, 1999.

[72] V. S. Barbosa, R. Wirth, C. M. Souza Motta, and I. R. Leal, "Fungos encontrados em ninhos de formigas cortadeiras (Atta laevigata) em fragmentos de floresta atlântica no nordeste do Brasil," in 6th Congresso de Ecologia do Brasil, 2003.

[73] V. S. Barbosa, Efeito da fragmentação florestal na taxa de parasitismo de fungos associados ao jardim da formiga cortadeira Atta laevigata, Master dissertation, UFPE, Recife, Brazil, 2004.

[74] S. E. Craven, M. W. Dix, and G. E. Michaels, "Attine fungus gardens contain yeasts," Science, vol. 169, no. 3941, pp. 184 186, 1970.
[75] F. C. Pagnocca, S. C. Carreiro, O. C. Bueno, M. J. Hebling, and O. A. Da Silva, "Microbiological changes in the nests of leaf-cutting ants fed on sesame leaves," Journal of Applied Entomology, vol. 120, no. 5, pp. 317-320, 1996.

[76] S. C. Carreiro, F. C. Pagnocca, M. Bacci, O. C. Bueno, M. J. A. Hebling, and W. J. Middelhoven, "Occurrence of killer yeasts in leaf-cutting ant nests," Folia Microbiologica, vol. 47, no. 3, pp. 259-262, 2002.

[77] W. J. Middelhoven, A. Fonseca, S. C. Carreiro, F. C. Pagnocca, and O. C. Bueno, "Cryptococcus haglerorum, sp. nov., an anamorphic basidiomycetous yeast isolated from nests of the leafcutting ant Atta sexdens," Antonie van Leeuwenhoek, vol. 83, no. 2, pp. 167-174, 2003.

[78] S. C. Carreiro, F. C. Pagnocca, M. Bacci et al., "Sympodiomyces attinorum sp. nov., a yeast species associated with nests of the leaf-cutting ant Atta sexdens," International Journal of Systematic and Evolutionary Microbiology, vol. 54, no. 5, pp. 18911894, 2004.

[79] F. C. Pagnocca, M. F. C. Legaspe, A. Rodrigues et al., "Yeasts isolated from a fungus-growing ant nest, including the description of Trichosporon chiarellii sp. nov., an anamorphic basidiomycetous yeast," International Journal of Systematic and Evolutionary Microbiology, vol. 60, no. 6, pp. 1454-1459, 2010.

[80] A. E. Little and C. R. Currie, "Symbiotic complexity: discovery of a fifth symbiont in the attine ant-microbe symbiosis," Biology letters, vol. 3, no. 5, pp. 501-504, 2007.

[81] A. E. F. Little and C. R. Currie, "Black yeast symbionts compromise the efficiency of antibiotic defenses in fungus-growing ants," Ecology, vol. 89, no. 5, pp. 1216-1222, 2008.

[82] S. C. Carreiro, Pesquisa de fator killer e análise da degradação de polissacarídeos vegetais por leveduras associadas aos ninhos de Atta sexdens, Ph.D. thesis, UNESP, São Paulo, Brazil, 2000.

[83] S. B. Ribeiro, Caracterização de espécies bacterianas encontradas em ninhos de Atta sexdens L. e isolamento de Streptomyces de formigas da tribo Attini, Ph.D. thesis, UNESP, São Paulo, Brazil, 2000.

[84] F. L. Guedes, D. Atilli-Angelis, and F. C. Pagnocca, "Selective isolation of dematiaceous fungi from workers of Atta laevigata (Formicidae: Attini)," Folia Microbiologica. In press.

[85] M. Poulsen and C. R. Currie, "Complexity of insect-fungal associations: exploring the influence of microorganisms on attine ant-fungus symbiosis," in Insect Symbiosis, K. Bourtzis and T. A. Miller, Eds., vol. 2, pp. 57-77, CRC Press, Newbury, UK, 2006.

[86] A. Rodrigues, F. C. Pagnocca, M. Bacci, M. J. A. Hebling, O. C. Bueno, and L. H. Pfenning, "Variability of non-mutualistic filamentous fungi associated with Atta sexdens rubropilosa nests," Folia Microbiologica, vol. 50, no. 5, pp. 421-425, 2005.

[87] A. Rodrigues, F. C. Pagnocca, O. C. Bueno, L. H. Pfenning, and M. Bacci, "Assessment of microfungi in fungus gardens free of the leaf-cutting ant Atta sexdens rubropilosa (Hymenoptera: Formicidae)," Sociobiology, vol. 46, no. 2, pp. 329-334, 2005.

[88] A. A. Carlos, A. Rodrigues, L. C. Forti, M. M. Passador, and J. F. Sierra, "Filamentous fungi found in Atta sexdens rubropilosa colonies after treatment with different toxic bait formulations," Journal of Applied Entomology, vol. 135, no. 4, pp. 326-331, 2011.

[89] G. Carrión, L. Quiroz, and J. Valenzuela, "Hongos entomopatógenos de las hormigas arrieras Atta mexicana en México," Revista Mexicana de Micologia, vol. 12, pp. 41-48, 1996.

[90] A. Rodrigues, A. Silva, M. Bacci, L. C. Forti, and F. C. Pagnocca, "Filamentous fungi found on foundress queens of leafcutting ants (Hymenoptera: Formicidae)," Journal of Applied Entomology, vol. 134, no. 4, pp. 342-345, 2010. 
[91] F. C. Pagnocca, A. Rodrigues, N. S. Nagamoto, and M. Bacci, "Yeasts and filamentous fungi carried by the gynes of leafcutting ants," Antonie van Leeuwenhoek, vol. 94, no. 4, pp. 517 526, 2008.

[92] M. Autuori, "Contribuição para o conhecimento da saúva (Atta spp. - Hymenoptera - Formicidae): V - Número de formas aladas e redução dos sauveiros iniciais," Arquivos do Instituto Biológico, vol. 19, pp. 325-331, 1950.

[93] M. Autuori, "Contribuição para o conhecimento da saúva (Atta spp. - Hymenoptera - formicidae): II - O sauveiro inicial (Atta sexdens rubropilosa Forel, 1908)," Arquivos do Instituto Biológico, vol. 13, pp. 67-86, 1942.

[94] A. Rodrigues, F. C. Pagnocca, O. C. Bueno, M. Bacci Jr., M. J. A. Hebling, and L. H. Pfenning, "Contaminação de ninhos de Atta sexdens rubropilosa Forel, 1908 (Hymenoptera: Formicidae) com esporos de fungos filamentosos," Arquivos do Instituto Biológico, vol. 71, pp. S149-S227, 2004.

[95] E. Lopez and S. Orduz, "Metarhizium anisopliae and Trichoderma viride for control of nests of the fungus-growing ant, Atta cephalotes," Biological Control, vol. 27, no. 2, pp. 194-200, 2003.

[96] E. Freinkman, D. C. Oh, J. J. Scott, C. R. Currie, and J. Clardy, "Bionectriol A, a polyketide glycoside from the fungus Bionectria sp. associated with the fungus-growing ant, Apterostigma dentigerum," Tetrahedron Letters, vol. 50, no. 49, pp. 6834-6837, 2009. 

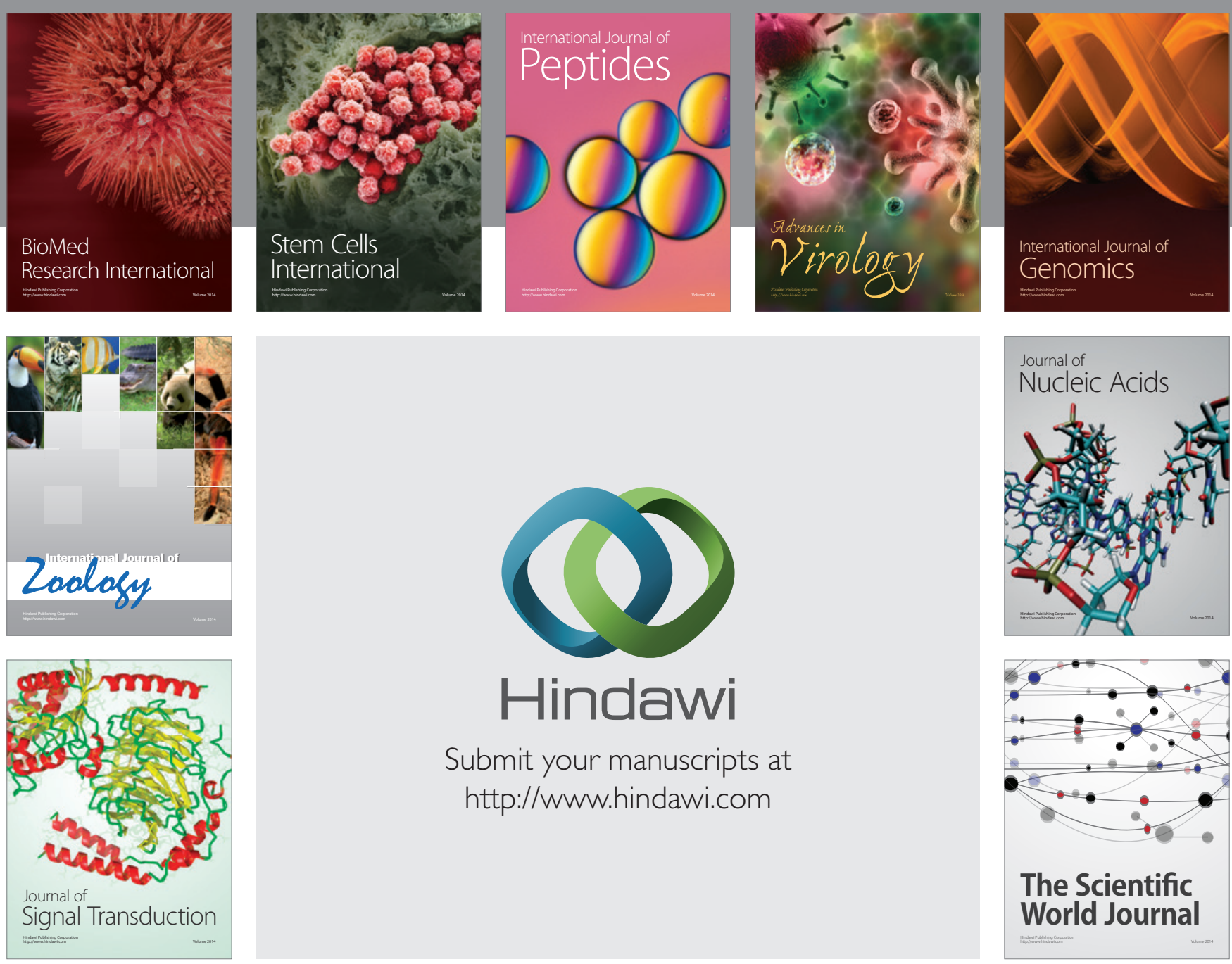

Submit your manuscripts at

http://www.hindawi.com
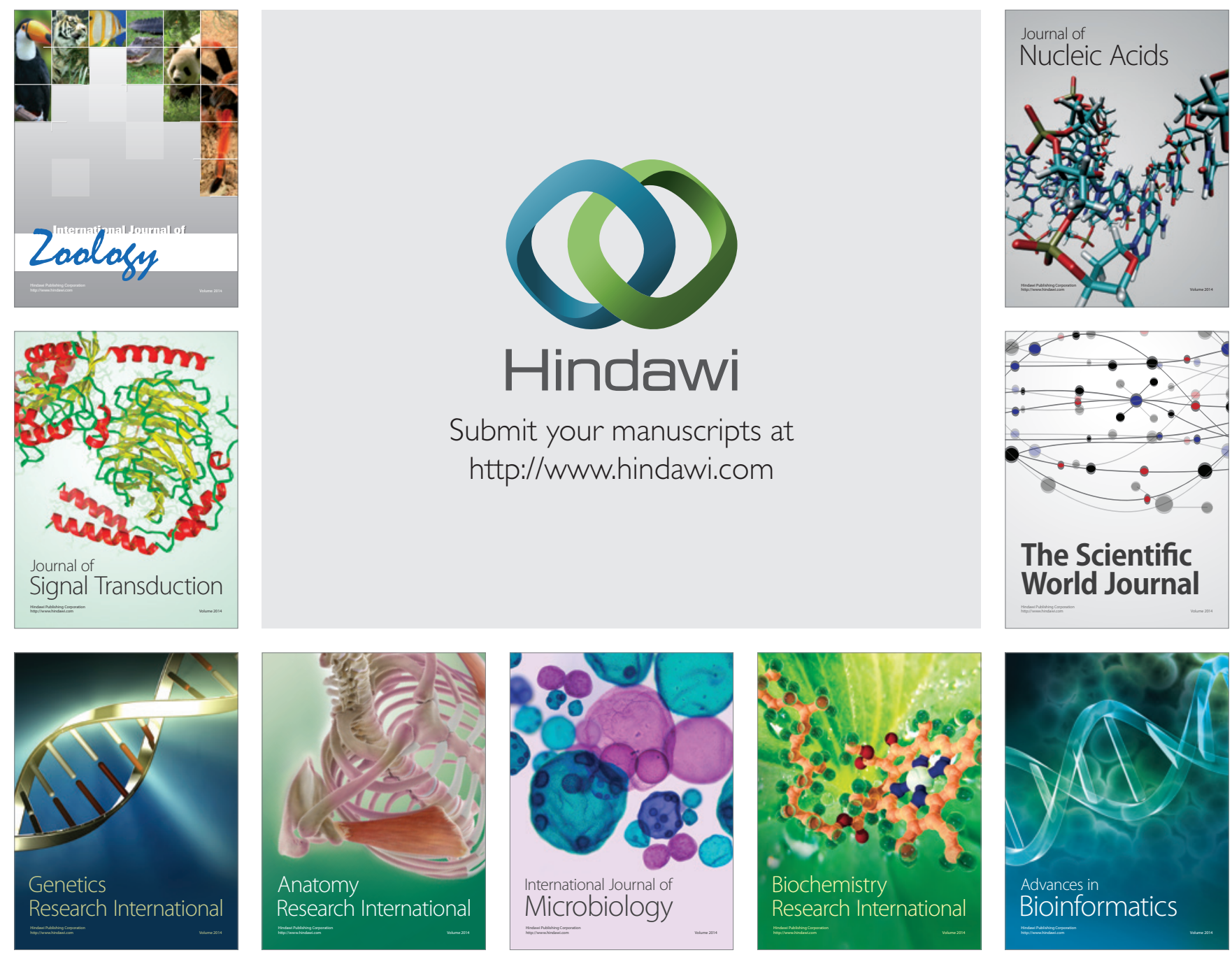

The Scientific World Journal
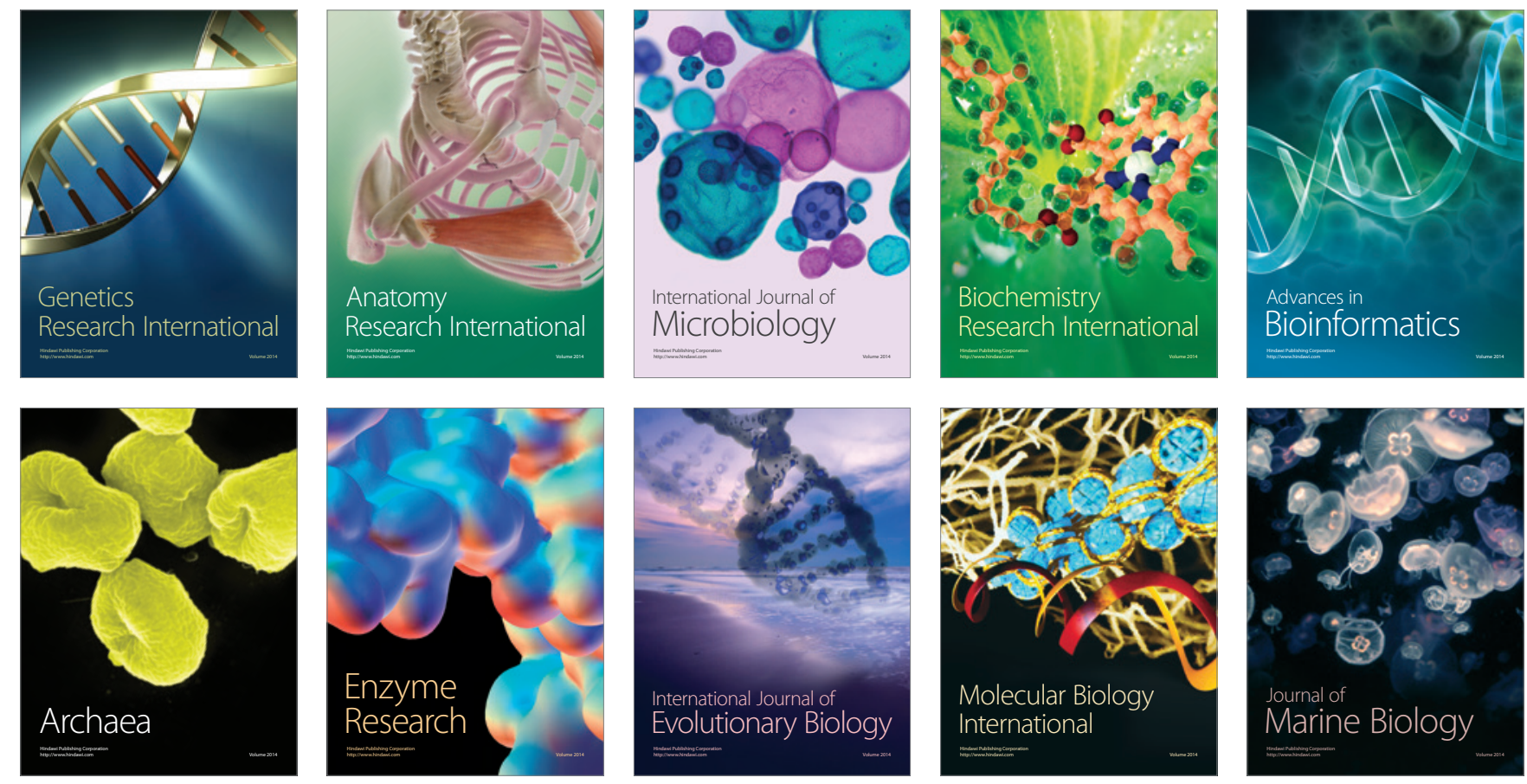